\title{
Tarihsel Boyutu ile Kamu Alım Usullerindeki Gelişmeler ve Günümüzdeki Yapının Değerlendirilmesi
}

\author{
Developments of Public Procurement Procedures in Historical \\ Dimension and Assessment of Today's Framework
}

\author{
Özhan Çetinkaya* \\ Murat Filibe \\ Kamuran Üstün ${ }^{* *}$
}

\section{Öz}

Kamu alımları geçmişten günümüze kabul edilen ihale kanunları ile gerçekleştirilmiştir. İlk ihale kanunu 1925 tarihli iken günümüzde geçerli olan son kanun 2002 tarihlidir. 1925 yılından günümüze kadar dört kanun değişmiştir. Bu kanunlarda yer alan alım usulleri ad olarak değişse bile içerik olarak fazla değişikliğe uğramamıștır. Alım usulleri içinde tüm kanunlarda temel usul; günümüzdeki adı ile açık ihale usulü olmuştur. Günümüz itibariyle değişikliklerin konuşulduğu ihale kanununda tarihsel boyutu ile bakıldığında değişmeyecek olan temel usulün yine açık ihale usulü olacağını söylemek yanlış olmayacaktır. Ancak çalışmada da ele alındığı üzere açık ihale usulünün yanında yer alan diğer alım usullerinin de önemli büyüklüklere ulaştığını belirtmek gerekir.

Anahtar Kelimeler: Kamu İhale Mevzuatı, İhale Kanunu, Kamu Alım Usulleri, Kamu İhaleleri, Açık İhale Usulü.

\begin{abstract}
Public procurement has been realized with tender laws that are accepted on from past to present. While the first tender law was dated 1925, the last law that is valid today is dated 2002. From 1925 to the present day four laws have amended. Even though the purchasing procedures included in these laws have changed as names, they have not changed much in terms of content. In the procurement procedures of all four laws, open tendering has been basic procedure with the different names. While the amendments are on the agenda about the current tender law, it will not be wrong to say that the open tendering will remain as the basic procedure in the new tender law from a historical point of view. However, as discussed in the study, it should be noted that other procurement procedures besides the open tender procedure have also reached significant sizes.
\end{abstract}

Keywords: Public Procurement Legislation, Tender Law, Public Procurement Procedures, Public Procurements, Open Procurement Procedure.

* Prof. Dr., Uludağ Üniversitesi İ.İ.B.F. Maliye Bölümü, ozhanc@uludag.edu.tr.

** Uludağ Üniversitesi Sosyal Bilimler Enstitüsü, Yüksek Lisans Öğrencisi, 701612018@ogr.uludag.edu.tr.

*** Uludağ Üniversitesi Sosyal Bilimler Enstitüsü, Yüksek Lisans Öğrencisi, kustun@uludag.edu.tr. 


\section{Giriş}

Günümüz ekonomik sistemi içinde kamu kesimini oluşturan devlet ve diğer idareler, kamu hizmetlerini üretmek ve sunmak üzere gerek kendi imkânlarını gerekse özel kesimin imkânlarını kullanmak zorundadırlar. Kamu kesiminin özel kesimden sağlayacağı mal ve hizmetlerin boyutu ekonomik büyüme çerçevesinde değişebilmektedir. Büyümenin durumuna göre alımlar azalıp, artabilmektedir. Ancak değişmeyen durum, alım türlerinin değişmemesi ve ylllar boyunca kamunun özel sektörden mal, hizmet ve yapım işi şeklinde alımlar yapmasıdır. Kamunun özel sektörden yaptığı alımlarda öne çıkan husus, alımların türü ve boyutu olduğu kadar bu alımların nasıl yapıldığıdır. Diğer bir deyişle yapılan alımların hangi özel sektör firmalarından nasıl temin edileceği konusunun taşıdığı önemdir. Bu hususta öne çıkan düşünce, alım usullerinin nasıl belirlendiği ve uygulandığı üzerine yoğunlaşmaktadır. Kamu alımlarında kullanılan usuller kamu ihale mevzuatı kapsamında geçmişten günümüze belirlenmiş olup yaşanan değişmelerle günümüzdeki yapı oluşturulmuştur. Çalışmada geçmişten günümüze kamu alım usulleri çerçevesinde kuramsal yapı açıklanarak günümüzde kamu alım usullerinin değerlendirilmesi yapılmıştır.

\section{Kamu Alımlarının Kuramsal Çerçevesi ve Türkiye}

20. yüzyılın ilk yarısında yaşanan Dünya Savaşları ve Büyük Buhran sonrasında klasik iktisat anlayışından uzaklaşılarak devletin ekonomiye müdahalesinin kaçınılmaz olduğunu savunan Keynesyen görüşün benimsenmesi ile birlikte kamu kaynakları maliye politikalarının yönlendirildiği amaçlar doğrultusunda en etkin şekilde kullanılmaya çalışılmıştır. Bu etkin kullanımın sonucunda ise kaynakları optimal şekilde dağıtmak, üretim faktörlerinin verimliliğini sağlayarak istihdam yaratmak, ekonomik kalkınmayı sağlamak gibi çıtılar elde edilmesi beklenmiştir. Her ne kadar 1980'li yılların başından itibaren ekonomide liberal rüzgârlar yeniden esmeye başladıysa da günümüze kadar geçen sürede kamu harcamalarının gayri safi milli hasıla içindeki artışı devam etmiştir. Bu artışta elbette tek başına kamu harcamalarının bir maliye politikası aracı olarak ekonomiye müdahale maksatlı kullanılması yoktur. Bu süreçte devletin sosyal devlet anlayışı çerçevesinde topluma sunmak durumunda olduğu hizmetlerin nüfus artışı, kentleşme, teknolojik gelişmeler gibi hususlara bağlı olarak artması ile liberal politikalar neticesinde devletin küçülmesine paralel olarak toplumsal hizmet sunumlarının özel kesime gördürülmesi gibi olguların da etkisi bulunmaktadır. Bu gelişmeler neticesinde 20. yüzyılın başlarında sanayileşmiş ülkelerde kamu harcamaları/gayri safi milli hasıla oranı \%10'un altında izlerken 1960'larda bu oran \%27’ye, 1990’lı yıllarda ise \%50 düzeyine kadar çıkmıştır(Kanca, Bayrak, 2015, s. 108).

Devletin ve diğer idarelerin üstlendiği toplumsal ve ekonomik görevlerini yerine getirirken kamu gelirlerini kullanarak yaptığı harcamaları "kamu harcamaları" genel ifadesiyle tanımlamak mümkündür. Kamu harcamaları; devlet mekanizmasının aksamaksızın işleyişinde gerekli olan (personel giderleri, bakım ve onarım giderleri vb.) cari harcamaları, faydası ileriki 
dönemlere dönük ve üretimin artırılması gibi belli amaçlara yönelik yatırım harcamalarını ve sosyal, ekonomik vb. nedenlerle yapılarak karşılığında herhangi bir mal, hizmet alınmayan transfer harcamalarını da kapsayan oldukça geniş bir alandır(Edizdoğan, Çetinkaya ve Gümüş, 2015, s.88-91). Bu nedenle kamu harcamaları ekonomik açıdan yatırım ve üretim miktarları ile kaynak dağılımı gibi unsurları etkilemekte; ayrıca kamu hizmetlerinin sunumu ve gelir dağılımını düzenlemek gibi fonksiyonları sağlamaktadır(Arslan, 2002, s.6). Bu geniş alanın içerisinde "kamu alımları" ise devlet organlarının ihtiyaç duyduğu mal, hizmet ve yapım işlerinin piyasadan alım sürecidir(Arrowsmith, Kunzlik, 2009, s.36). Günümüzde devletler devlet olmanın getirdiği sorumlulukla bir yandan üretim kapasitesinin artırılmasına yönelik yatırım harcaması olarak da adlandırılan birçok alt yapı projesini gerçekleştirirken bir yandan da toplumsal hizmetler ile diğer cari faaliyetlerini yerine getirmek için mal, hizmet ve yapım işleri alımları yapmaktadırlar.

Kamu alımları büro işlerinde kullanılacak bir kalemden otoyol inşasına kadar geniş bir çeşitliliğe sahiptir(Wiehen, Olaya, 2006, s.13). Bu nedenle kamu alımları hem alıcı konumundaki devlet hem de ekonomide faaliyet gösteren farklı büyüklüklerdeki tüm özel kesim tarafları için büyük önem taşımaktadır. Bu harcamaların ekonomik faaliyetler içindeki yerini görebilmek açısından 2009-2015 yılları arası OECD verileri incelendiğinde Türkiye’nin de içinde olduğu OECD ülkelerindeki kamu alımlarının kamu harcamalarına ortalama oranının \%30 seviyesinde olduğu görülmektedir.(Organization of Economic Co-operation and Development [OECD], 2017) Bu kapsamda aşağıdaki tabloda 2012-2016 yılları arasında Türkiye’de kamu eliyle yapılan alımların miktarı Türk Lirası ve Amerikan Doları cinsinden verilmiştir.

Tablo I: Toplam Kamu Alımları

\begin{tabular}{|l|l|l|}
\hline Yllar & Toplam Kamu Alımları $\mathbf{( 1 . 0 0 0}$ TL) & Toplam Kamu Alımları (1.000\$) \\
\hline 2012 & 94.398 .722 & 53.942 .126 \\
\hline 2013 & 105.504 .100 & 46.683 .230 \\
\hline 2014 & 113.494 .916 & 49.345 .615 \\
\hline 2015 & 148.434 .787 & 50.359 .554 \\
\hline 2016 & 173.663 .835 & 49.054 .809 \\
\hline TOPLAM & $\mathbf{6 3 5 . 4 9 6 . 3 6 0}$ & $\mathbf{2 4 9 . 3 8 5 . 3 3 4}$ \\
\hline
\end{tabular}

Not. 2012-2016 yillarına ait Kamu İhale Kurumu(KİK) Kamu Alımları İzleme Raporlarında belirtilen değerler ve dolar kurları kullamılarak tarafimızdan hazırlanmıştır.

Tablo 1'deki verilerden de görüldüğü üzere Türkiye'de son beş yılda Kamu İhale Kurumu tarafından izlenen kamu alımları ortalaması 50 Milyar ABD doları seviyesindedir. Bununla birlikte yine OECD verilerine göre Türkiye'de yapılan kamu alımları 2009-2015 yılları arasında ortalama olarak GSYH'nın \%11’i oranında gerçekleşmiştir(OECD, 2017). Bahse konu veriler her yıl yapılan kamu alımlarının ekonomi içinde ne denli büyük bir rolü olduğunun somut göstergesi olarak karşımıza çıkmaktadır. Kamu alımlarının ulusal ve uluslararası düzeydeki büyüklügü bahse konu alımları devletlerin; küresel düzeyde rekabet ile ulusal çıkarlar gibi alanlarda dengeyi sağlamaya 
ve toplumun şeffaflık, etkinlik, eşitlik, adalet beklentilerini karşılamaya çalıştıkları karmaşık bir yapı haline getirmektedir(Thai, 2009, s.2). Ancak bu karmaşık yapıda bulunması gereken ve genel kamu yönetimiyle de uyumlu olan temel üç unsur vardır. Bunlar; toplumun kamu alımları sürecine adalet, eşitlik, şeffaflık, hesap verilebilirlik nitelikleri açısından güveni, etkinlik ve verimlilik, politikalara uyumluluk ve devamlılık (Schapper, Malta\&Gilbert, 2009, s.89).

Kamu alımlarının ekonomi içindeki büyüklüğü ve bunun neticesindeki karmaşık yapısı bu alımları küreselleşme olgusu ile birlikte sadece devletlerin sınırlarını belirlediği bir alan olmaktan çıkararak Birleşmiş Milletler, Dünya Ticaret Örgütü, Ekonomik Kalkınma ve İşbirliği Örgütü gibi küresel düzeyde ve Avrupa Birliği gibi bölgesel düzeyde uluslararası kuruluşlar tarafından da ülkeler düzeyinde belli sabit standartlara ulaşmak maksadıyla üzerinde normlar geliştirilen bir alan haline getirmiştir. Bu çerçevede UNCITRAL Kamu Alımları Model Kanunu ve Avrupa Birliği Kamu Alımları Direktifleri öne çıkan örneklerdir(Akdoğan, 2014, s.683).

Kamu alımlarında ulusal ve uluslararası normlara göre değişen farklı yöntemler kullanılsa da genel kabul gören ortak usul ihale yöntemidir(İlkorkor, 2010, s.65). Türkiye’de günümüze kadar yapılan hukuki düzenlemelerde ihale veya kamu ihalesi kavramları kamu alımları için kullanılagelmiş olmasına karşın ihale yöntemi sadece kamu alımlarında kullanılan bir yöntem olmayıp kamuya gelir getiren satış, özelleştirme gibi hususlarda da kullanılmaktadır(Akdoğan, 2014,s.685). Kamu alımları perspektifinden ihale; kamu idarelerinin görevlerini yerine getirmekte ihtiyaç duydukları mal ve hizmeti hukuki düzenlemelere uygun olarak özel kesimde en uygun teklif verenden alma sürecidir.

Kamu alımlarının kaynağının kamu gelirleri olduğu göz önüne alındığında kamu kaynaklarının etkin ve verimli kullanılmasından hareketle miktar olarak büyük, yapı olarak karmaşık ve sosyoekonomik öznelerde etkisi olan kamu alımlarının tereddütlere mahal vermeyecek şekilde hukuki zemine oturtulmuş ancak yeniliklere açı olan dinamik bir süreç içinde gerçekleştirilmesi büyük önem arz etmektedir(Kaplan, 2012, s.21). Bu kapsamda cumhuriyetin kuruluşundan günümüze kadar ülkemizde dört kanuni düzenleme yapılmıştır. Bunlardan ilki 22 Nisan 1925 tarihli ve 661 sayılı Hükümet Namına Vukubulacak Müzayede ve Münakaşa ve İhalât Kanunu; ikincisi 2 Haziran 1934 tarihli ve 2490 sayılı Artırma, Eksiltme ve İhale Kanunu; üçüncüsü 8 Eylül 1983 tarihli ve 2886 sayılı Devlet İhale Kanunu ve son olarak dördüncüsü ise 4 Ocak 2002 tarihli ve 4734 sayılı Kamu İhale Kanunu'dur. Diğerlerinin aksine son kanun olan 4734 sayılı Kanun kamu satışlarını kapsamamakta sadece kamu alımlarını düzenlemektedir(Büber, 2014, s.94).

1990'lı yılların sonunda halen yürürlükte olan 2886 sayılı Devlet İhale Kanununun, Türkiye’nin Uluslararası Para Fonu ve Dünya Ticaret Örgütü ile yürüttügü ilişkiler ve AB üyeliği müzakereleri kapsamında yapılan tespitler neticesinde yetersiz kaldığı görülmüştür(Akdoğan, 2014,s.692). 2886 sayılı Kanunun başta Avrupa Birliği olmak üzere uluslararası uygulamalara cevap verememesi; rekabet, şeffaflık gibi unsurları sağlamada yetersiz kalması, yeniçağın değişen ihtiyaçlarını karşılayamaması gibi nedenlerle kamu alımlarının yeniden düzenlenmesi kapsamında yeni bir kanun hazırlıklarına başlanmış ve sonucunda 1 Ocak 2003 tarihinden itibaren geçerli olmak 
üzere 4734 sayılı Kamu İhale Kanunu 4 Ocak 2002 tarihinde kabul edilmiştir(Çolak, 2014, s.115). Ancak yapılan yeni düzenlemeyle birlikte 2886 sayılı Kanun tamamıyla yürürlükten kalkmamış, devlete gelir getirici özellikteki satış, kira ve trampa gibi işlemlerin yerine getirilmesinde kullanılmaya devam edilmesi sağlanmıştır. Bu şekilde kamunun alım ile satım faaliyetlerini düzenleyen mevzuat birbirinden ayrılmıştır. 4734 sayılı Kamu İhale Kanunu kamu alımlarını üç ana grupta toplamıştır. Bunlar mal alımları, hizmet alımları ve yapım işleridir. 1980 yılların ortalarından itibaren özelleştirme uygulamaları, özel sektörün hizmet alanındaki çeşitliliğini ve arzını artırmış, kamu idarelerinin devletin personel rejimine bağlı olarak temizlik, toplu taşıma gibi çeşitli hizmetleri özel sektörden tedarik etmeye başlaması vb. nedenlerle ciddi boyutlarda artış gösteren hizmet alımları da yeni kanunda temel kamu alımları arasına girmiştir(Büber, 2008, s.135-208).

\section{Kamu İhale Kanunlarının Tarihsel Gelişimi}

Kamunun gerçekleştirdiği alımlarda uygulanacak olan alım usulleri Tablo 1'de gösterilen alımların toplam büyüklükleri de dikkate alındığında her dönem önem arz etmiştir. Diğer bir deyişle kamu alımlarının büyüklükleri göz önüne getirildiğinde ihale mevzuatı kapsamında yer alan alım usullerinin önemi ortaya çıkmaktadır. Geçmişten günümüze ihale mevzuatı kapsamındaki alım usullerinde yaşanan değişimler "kamu daha uygun şartlarda alımlarını nasıl gerçekleştirebilir?" sorusuna cevap bulmak üzere yaşanmıştır. Bu kapsamda çalışmanın bu kısmında geçmişten günümüze değişen mevzuat kapsamındaki kamu alım usullerini açıklamak çalışmanın sonucu ve değerlendirme kısmı için önem taşımaktadır.

\section{Müzâyede ve Münâkasa ve Ihâlât Kanunu}

Ülkemizde kamu alımlarını düzenleyen ilk yasal metin Cumhuriyetin ilanından sonra 28 Nisan 1925 tarih ve 661 sayıl Hükûmet Nâmına Vukû’ Bulacak Müzâyede ve Münâkasa ve İhâlât Kanunu’dur. Kanuna göre, idare adına yapılacak her çeşit satın almalar; satış, kira, inşaat, tamirat, keşifler ve imalat (üretim) ve işletme, nakliyat ve benzeri işlerin eksiltme veya artırma işlemleri kapalı zarf usulüyle artırma veya eksiltme, açık artırma ve eksiltme ve pazarlık suretiyle ihale usulleri ile yapılması hükme bağlanmıştır.

Kanunda esas olan kapalı zarf usulüyle artırma veya eksiltmedir. Bu usulde bir zarf içerisine konulan teklif mektubu mühürlenir ve zarfın üzerine teklifin hangi işe ait olduğu ve isteklinin isminin yazılır. Zarflar ilgililer tarafından eksiltme ve artırmanın gün ve saati gelmeden evvel sıra numaralı bir makbuz karşılığında artırma veya eksiltmeyi yapmaya görevli heyetin başkanlığına verilir ve heyet tarafından zarflar açılıp artırma veya eksiltmeye girebilecekler için aranılan şart ve teminatın yerine getirilip getirilmediği incelenir ve şartları yerine getirmeyenlerin zarfları açılmadan iade olunur. Açı oturumda teklifler gerçek değerine uygun olup olmadığına göre incelenir ve en uygun teklif veren istekli ile sözleşme imzalanır. 
Kanunda yer alan Açık Artırma ve Eksiltme ihale usulü ise artırma ve ihalesi özel hükümlerine uyarak yapılacak olan vergiler, senelik kira bedeli beşbin liraya kadar olan idareye ait taşınmaz malların kiralanması, artırma bedeli ve eksiltilmesi beşbin lirayı geçmeyen satın almalar, ithalat, fiyatı kapalı zarf usulünün uygulanmasına olanak vermeyen hususlar (Maliye Bakanlığının iznini gerektiren şartlar) ile ilgili olarak gerçekleştirilir("Cumhuriyet dönemi ihale”, 2017). Bu usul açık ihale olarak gerçekleşen işlemler için ihale gün ve saatinde hazır bulunanlar arasından en uygun teklif verenin tercih edildiği bir usuldür.

Pazarlık usulünde belirli limiti aşmayan çeşitli satın almalar ile Bayındırlığa ait devamlı veya acele tamirat işlerinde, kesinleşen ihalede uhdesinde ihale kalanların ihale şartlarını yerine getiremediklerinden dolayı zarar ve hasarı gidermek için hükümet tarafından nakliyat, inşaat ve satın almalar, nakliye vasıtaları ile yapılacak nakliyat, Hükümet tarafından emaneten yapılması uygun görülmeyen keşifler, işlemleri gizli tutulması gerekli olan işler pazarlık usulü ile yapılır.

Bayındırlık inşaatı ve işletme emirleri bu kanuna tabi olmayıp özel bir kanuna dayanak olmak şartıyla emanet usulü ile yapılabilecektir(“Cumhuriyet dönemi ihale”, 2017).

$\mathrm{Bu}$ kanunda yer alan ihale usullerinden anlaşılan husus, alınacak mal ya da yapılacak işlerde rekabetin sağlanması düşünülmüş bu kapsamda işin ya da malın miktar ve türüne göre farklı usullerden yararlanılmıştır.

\section{Artırma, Eksiltme ve Ihale Kanunu}

661 sayılı Kanunun yürürlükte kaldığı süre içerisinde karşılaş1lan ihtiyaçlar çerçevesinde 779, 878, 1330, 1540 ve 2338 Sayılı kanunlarla değişikliklere gidilmiş ancak bu değişikliklerde idari yapının gelişen fonksiyonları karşısında ihtiyacı karşılamamış(Yılmaz, 2007, s.61), Kanun 10 Haziran 1934 yılında yerini yaklaşı 50 yıl yürürlükte kalan 2490 sayılı Artırma, Eksiltme ve ihale Kanunu’na(Artırma, Eksiltme ve İhale, 1934) bırakmıştır.

2490 sayılı Kanuna göre bazı idareler hariç, idareler adına alım, satım, yapım, keşif, kiraya verme, kiralama ve bunlara benzer diğer işler; kapalı zarf usulü, açık artırma ve eksiltme, mahdut(dar) eksiltme, pazarlık usulü ve emanet usulü ile yapılacağı hüküm altına alınmıştır.

Kanunda esas ihale usulü kapalı zarf usulüdür. İstekliler mühürlü bir zarf içerisinde teklifleri ile birlikte teminat makbuzları ve banka teminat mektupları ile diğer istenilen evrakları artırma ve eksiltmeyi açma saatinden bir saat öncesine kadar artırma ve eksiltmeyi yapacak olan komisyonu başkanlığına verir. Komisyon tarafından teklifler kontrol edildikten sonra en uygun bedel teklif edene ihale verilir.

Tahsili ve ihalesi özel kanunlara göre yapılacak olan resimler, belirli bir parasal değere kadar olan kiralama, alım, nakil, yapı ve tamir işleri açık artırma ve eksiltme usulü ile yapılır. İhale gün ve saatinde komisyon isteklilerin teklifleri arasında en uygun teklif veren istekliye ihale bırakılır. 
Mahdut eksiltme usulünde idareler, tecrübe edilmiş firmalara ihalesi lüzumlu görülen uçak, harp gemisi, harp, mühimmatı alimi, askerî tesisat ve levazımı, liman, rıhtım, şimendifer, demiryolları inşası, büyük su tesisatı, büyük fabrika ve diğer sanayi tesisat ile sıhhî tesisat işlerini, yaptıkları işlere eksiltmeye gidebilmesidir.

Kanunun 46. Maddesinde pazarlık usulü ile ihale yapılacak işlerden bazıları; artırma, ve eksiltmeye konulması faydalı görülmeyen müteferrik alımlar ile menkulât satışları ve küçük tamirler, yalnız tek kişide olan işler, güzel sanatlara özel matba ve elişleri, devlete ait her hangi bir hizmet için satın alınacak ya da kiralanacak gayrimenkullerdir.

Keşif bedeli belirli bir parasal değeri geçmeyen resmi idarelerin binaları, yolları, köprü inşa veya tamirleri, yasak araziler içerisindeki mahsül ve meyve ağaçları hasılatları, tuz çıkarma işleri ve eksiltme veya pazarlık usulüyle ihalesi mümkün olmayan yapı, imal ve tamir işlerinin emanet usulü ile yapılacağı(Artırma, Eksiltme ve İhale, 1934) belirtilmiştir.

\section{Devlet Ihale Kanunu}

İkinci Dünya Savaşı ve sonrasında, milletlerarası ticarî ilişkilerde ve ülkemizin ekonomi ve idari bünyesindeki büyük değişiklikler, devlet alım ve satımlarında hızlı ve pratik usullerin gerekliliğini açığa çıkarmıştır. 2490 sayılı Kanun, uzun zaman uygulanması ve az sayıda değişiklik yapılmasına rağmen, katı ve esnek olmayan hükümleri ile özellikle planlı kalkınma döneminin ihtiyaçlarına cevap vermemiştir. Kanunun ihtiva ettiği katı hükümleri, zaman kaybına sebebiyet veren formaliteleri, bazı idarelere bir kısım ihtiyaçlarının ve yapım işlerinin Kanuna tabi olmaksızın pazarlıkla ve emaneten yaptırması, konusunda zaman zaman getirilen geçici istisna ve yetkiler, planlı dönemin hızlı ve güven içinde yürütülmesi zorunluluğu yeni bir kanunun hazırlanmasına neden olmuş ve 10.09.1983 tarihinde Resmi Gazetede yayımlanan 2886 sayılı Devlet İhale Kanunu yürürlüğe konmuştur.( Türkiye Büyük Millet Meclisi [TBMM] , 1981, s.1)

2886 Sayılı Devlet İhale Kanunun kapsamı genel bütçeye dahil idarelerle katma bütçeli idarelerin, özel idare ve belediyelerin alım, satım, hizmet, yapım, kira, trampa, mülkiyetin gayri ayni hak tesisi ve taşıma işleridir. İdareler, kapalı teklif usulü, belli istekliler arasında kapalı teklif usulü, açık teklif usulü, pazarlık usulü ve yarışma usulü ile Kanun kapsamındaki işlemlerini yerine getirir.

İhalelerde esas olan kapalı teklif usulünde, istekliler adı, soyadı ve tebligata esas göstereceği adresi yazılı olan mühürlü teklif zarlarını ilan saatine kadar komisyon başkanlığına gönderir. Komisyon geçerli en yüksek teklifin altında olmamak üzere, oturumda hazır bulunan isteklilerden sözlü veya yazılı teklif alınmak suretiyle ihale sonuçlandırılır.

2886 sayıl Kanunda "Uçak, harp gemisi, harp mühimmatı, elektronik cihaz, askeri tesisat ve levazımat, silah ve malzeme sistemleri, savunma sanayii ile ilgili faaliyetler ve bunlara ait her türlü yedek parça alımi; barajlar, enerji santralleri, sulama tesisleri, limanlar, rihtımlar, hava meydanları, 
demiryolları, lokomotifler, karayolları, tüneller, köprüler, akaryakıt tesisleri, özelliği bulunan yapım işleri bedii ve teknik hususiyetleri taşıyan sanat işleri, kentlerin ulaşım sistemlerine iliş̧kin planlar, kentlerin harita, nazım ve imar planları, su, kanalizasyon ve enerji tesisleri ile bunların etüt ve proje işlerinin ihalesi; diğer ihale usulleri yerine teknik yeterlilikleri ve güçleri idarece kabul edilmiş en az üç istekli arasında kapalı teklif usulü ile yaptırılabilir." ifadesi yer almıştır.

Açık teklif ihale usulünde ihale saati gelmeden önce istekliler gerekli belgelerini komisyona verirler. Artırma ve eksilme usulü kapsamında istekliler verdikleri tekliflerin görüşülmesini müteakip yazılı olarak son tekliflerini vererek ihalenin karara bağlanmasına çalışılır.

Pazarlık usulü ise Kanunun 51. Maddesinde belirtilen işlerde kullanılan bir usuldür. Pazarlık usulü ihalelerde tekliflerin alınması ile ilgili belirli bir şekle tabi olmayıp ihaleler komisyon tarafından işin nitelik ve gereğine göre bir veya birden fazla isteklilerden yazılı veya sözlü teklif alınarak yapılır.

Yarışma usulü ise idarelerin her türlü etüt, plan, proje ve güzel sanatlara ilişkin işleri yaptırabildiği bir usul(Devlet İhale, 1983) olarak kanunda yerini almıştır.

\section{Kamu ihale Kanunu}

2886 Sayılı Devlet İhale Kanununun tüm kamu kurumlarını kapsamadığı, uygulamada ortaya çıkan sorunları gidermede yetersiz kaldığı, çağımızın değișen ve gelişen ihtiyaçlarına cevap vermediği, Avrupa Birliği ve uluslararası ihale uygulamalarına paralellik göstermediği görülmüştür. Ayrıca, kanunda belirtilen kamu harcaması ve kamu gelirlerini ilgilendiren işlerin farklı nitelikte olmalarına rağmen aynı kanunla düzenlenmesinin uygulamada ortaya çıkardığı sorunların(TBMM, 2001, s.1)önemsenecek düzeyde olması 2886 sayılı Kanunun değiştirilmesini gerektirmiştir. Bunlarla birlikte Türk kamu ihale sisteminin AB ve Dünya Ticaret Örgütü gibi uluslararası kuruluşların ihale mevzuatları ile uyumlu hale getirilmesi, kamu ihaleleri alanında uygulamayı yönlendirip denetimini sağlayacak bağımsız bir kurumun tesis edilmesi, kamu kaynaklarında israfın önlenmesi ve verimli kullanımı ile rekabet ve eşit muamelenin sağlanması ilkelerinin tam olarak uygulanabilmesi, etkin, şeffaf ve güvenilir bir kamu ihale sisteminin kurulması amacıyla yeni bir ihale kanununa ihtiyaç duyulmuştur(Köktaş, 2005, s.17-18).

Kanunun değiştirilmesi yönünde oluşan önerilerle birlikte, 2000'li yılların başında başlayan kamu alımları reform çalışmaları sonucunda AB direktifleri ve UNCITRAL Kamu Alımları Model Kanunu ilkeleri baz alınarak, şeffaflık ve rekabet adına reform niteliğinde değişiklikler getiren 4734 sayılı Kamu İhale Kanunu ve 4735 sayılı Kamu İhale Sözleşmeleri Kanunu hazırlanmıştır(Akdoğan, 2014, s.683).

4734 sayılı Kamu İhale Kanunu 1 Ocak 2003 tarihinde yürürlüğe girmek üzere 22 Ocak 2002 tarihli 26648 sayılı Resmi Gazetede yayımlanmıștır. Kanunun amacı, ihalelerde saydamlı̆̆ın, rekabetin, eşit muamelenin, güvenirliğin, kamuoyu denetiminin, gizliliğin, ihtiyaçlara uygun 
şartlarda ve zamanında karşılanmasının ve kaynakların etkin ve verimli kullanılmasını, tahmini bedel üzerinden indirim yapılarak ihale yapılması yerine, istekliler tarafindan piyasa değerlerine uygun fiyata gerçekçi ihale yapılmasıdır.

Kanununda uluslararası ihale uygulamalarına uyum sağlamak amacıyla Kanunun 18. maddesinde idarelerce yapılacak olan her türlü kaynaktan karşılaşılan mal veya hizmet alımları ile yapım işlerinde kullanılacak ihale usulleri; açık ihale usulü, belli istekliler arasında ihale usulü, pazarlık usulü ve doğrudan temin olmak üzere dört ihale usulü benimsenmiştir (TBMM, 2001, s.2). Ancak Kanun yürürlüğe girdiğinde kanunun uluslararası standartları ve ihalelerde açıklık, rekabet ve eşit muameleyi sağlayamadığı, uluslararası rekabete açık olmadığı, Avrupa Birliği direktifleri başta olmak üzere uluslararası standartlarla uyum içinde olmadığı, bazı maddelerin uygulanmasının idareler açısından fiilen imkânsız olduğu, bazı maddeler arasındaki çelişki ve tutarsızlıkların suiistimale açık olduğu gözlenmiştir. $\mathrm{Bu}$ eksiklikler karşısında kamu ihalelerinin sağlıklı biçimde yürütülmesini sağlamak üzere idarelerin bu konudaki yakınmaları ve uygulamanın izlenmesi neticesinde başta Avrupa Birliği, Dünya Bankası ve Birleşmiş Milletler normları olmak üzere uluslararası düzenlemeler de göz önünde bulundurularak kanunda 15 Ağustos 2003 tarihinde 25200 sayılı Resmi Gazetede "Bazı Kanunlarda Değişiklik Yapılması Hakkındaki Kanun” ile değişikliğe gidilmiştir. Değiş̧ikle birçok yeni düzenleme yapılmış onlardan biri de idarelerin küçük çaplı ihtiyaçlarını diğer ihale usullerine tabi olmadan basit biçimde karşılanması için doğrudan temin usulü getirildiği halde, çok küçük alımlarda dahi sözleşme yapılması, Kanunun 10 uncu maddesindeki yeterlilik şartlarının istenmesi vb. konuların doğrudan teminde de aranması uygulamada istenilen kolaylığı sağlayamadığı için doğrudan temin usulü ihale usulü olmaktan çıkarılmış ve alım usulü olmuş buna ilişkin esas ve usuller Kanunun 22 inci maddesinde düzenlenmiştir.(TBMM, 2003, s.6)

4734 sayılı Kamu İhale Kanununun 5 inci maddesi “Temel İlkeler” başlığı altında açık ihale usulü ile belli istekliler arasında ihale usulünün temel usul olduğunu diğer ihale usullerinin Kanunda belirtilen özel şartlarda kullanılabileceğini belirtilmiştir.

Temel ihale usulü olan açık ihale usulü, uluslararası mevzuatına uygun olarak işin niteliklerinin gerektirdiği yeterliliğe sahip bütün isteklilerin teklif verebildiği usuldür (TBMM, 2001,s.4). Kanuna göre, belli istekliler arasında ihale usulü, yeterlilik sonucunda idarelerce davet edilen isteklilerin teklif verebildiği, yapım işleri, hizmet ve mal alım ihalelerinden uzmanlık gerektiren açık ihale usulünün uygulanamadığı, yaklaşık maliyeti eşik değerin yarısını aşan yapım işi ihalelerinde uygulanan bir ihale usulüdür. Belli istekliler arasındaki ihale usulünde rekabeti engellemeyecek şekilde kanunun 10 uncu maddesine uygun olarak ön yeterlilik ve ön yeterlilik ilanında belirtilen değerlendirme kriterlerine göre teklif verebilecek adayları belirlemek üzere ön yeterlilik değerlendirilmesi yapılır. Yeterli olduğu belirlenen adaylar dokümanda belirtilen kriterlere göre sıralanarak listeye alınan belli sayıda istekliler teklif vermeye davet edilir. İşin niteliğine göre kanunun 40 incı maddesine uygun olarak ihale dokümanı ve davet mektubunda belirtilen kriterlere göre teklifler değerlendirilerek ihale sonuçlandırılır. 
Pazarlı usulü kanunda 21 inci maddesinde işlerin özelliği ve ivedilik gibi kriterlerin belirtiği hallerde kullanılabilen, ihale sürecinin iki aşamalı olarak gerçekleştirildiği ve idarenin ihale konusu işin teknik detayları ile gerçekleştirme yöntemlerini ve belli hallerde fiyatı isteklilerle görüştügü usuldür.

Son olarak ihale usulü olmamakla birlikte 22 inci madde de belirtilen şartlarda ilân yapılmaksızın ve teminat alınmaksızın doğrudan temin olarak adlandırılan alımlarda ihale yetkilisince görevlendirilecek kişi veya kişilerce piyasa araştııılması yapılmak şartı ile ihtiyaçların temin edilmesi sağlanır.

\section{Kamu Alımlarının Alım Usullerine Göre İncelenmesi}

Cumhuriyetin ilanından sonra kamu ihale mevzuatında bütünüyle kanun olarak dört kez değişikliğe gidildiği, ilk kanunla ikinci kanun arasında dokuz yıl, ikinci kanunla üçüncü kanun arasında elli yıl, üçüncü kanunla dördüncü kanun arasında ise yirmi yıl olduğu anlaşılmakta, kanunlar arasında alım usulleri yönüyle çalışmanın ikinci başlığında da değinildiği üzere temel de fazla değişikliğin olmadığı görülmektedir. Temel kamu alım usulü olarak birinci, ikinci ve üçüncü kanunda "kapalı zarf usulü" olarak adlandırılan usul, son düzenleme olan dördüncü kanunda ise "açık ihale usulü" adıyla temel usul olarak belirlenmiştir. Kanunlardaki açıklamalara göre kapalı teklif ile açık ihale usullerinin içerikleri alımlara aynı yönde yaklaşmaktadır. Temel alım usulü olan bu usullerde hedeflenen husus, alımları rekabete daha çok açarak devlet açısından daha ucuza ve faydalı alımlar haline getirilmesi olmuştur. Günümüze kadar yapılan kanuni düzenlemeler dikkate alındığında gelecekte yapılacak yeni kanun çalışmalarında açık ihale usulünün adı ne şekilde belirlenirse belirlensin içeriğinin önceki kanunlardan da anlaşılacağı üzere benzer şekilde olacağ yönünde görüş bildirmek doğru olur. Kamu alımlarının günümüzde çoğunluğunun ihale mevzuatı kapsamındaki rekabete açık usullerle yani açık ihale usulü ile yapıldığını çeşitli sayısal verilerle göstermek mümkündür.

\section{Kamu Alımlarının Kapsamına Göre Incelenmesi}

Kamu alımları; 4734 sayılı Kamu İhale Kanununda belirtilen ihale usulleri kapsamında alımlar, yine aynı kanun çerçevesinde "doğrudan temin" usulüyle alımlar, "istisnalar" kapsamında alımlar ve "kapsam dışında" yapılan alımları kapsamaktadır. Aşağıdaki tabloda Türkiye’de 2012-2016 yılları arasında yapılan kamu alımları belirtilen bu dört başlık altında toplanmıştır. 
Tablo 2: Kamu Alımlarının Kapsamına Göre Dağılımı (I.000 TL)

\begin{tabular}{|c|c|c|c|c|c|c|c|c|c|c|}
\hline \multirow{3}{*}{$\begin{array}{l}\text { Kamu Alımı } \\
\text { Kapsamı }\end{array}$} & \multicolumn{10}{|c|}{ KAMU ALIMI TUTARLARI } \\
\hline & \multicolumn{2}{|l|}{2012} & \multicolumn{2}{|l|}{2013} & \multicolumn{2}{|l|}{2014} & \multicolumn{2}{|l|}{2015} & \multicolumn{2}{|l|}{2016} \\
\hline & Tutar & $\%$ & Tutar & $\%$ & Tutar & $\%$ & Tutar & $\%$ & Tutar & $\%$ \\
\hline $\begin{array}{l}4734 \text { S.K. } \\
\text { İhale Usulleri } \\
\text { Kapsamındakiler }\end{array}$ & 76.634 .709 & 81,18 & 89.237 .530 & 84,58 & 97.420 .824 & 85,84 & 128.244 .122 & 86,4 & 155.661 .190 & 89,63 \\
\hline Doğrudan Temin & 10.554 .256 & 11,18 & 6.433 .774 & 6,1 & 7.419 .983 & 6,54 & 8.276 .761 & 5,58 & 3.817 .742 & 2,2 \\
\hline İstisna & 7.121 .725 & 7,54 & 9.213.471 & 8,73 & 8.393 .401 & 7,4 & 11.913 .904 & 8,02 & 14.184 .903 & 8,17 \\
\hline Kapsam Dışı & 88.033 & 0,09 & 619.325 & 0,59 & 260.708 & 0,23 & - & - & 0 & \\
\hline Genel Toplam & 94.398 .722 & 100 & 105.504 .100 & 100 & 113.494 .916 & 100 & 148.434 .787 & 100 & 173.663 .835 & 100 \\
\hline
\end{tabular}

Not. 2012-2016 yıllarına ait KİK Kamu Alımları İzleme Raporlarındaki değerler kullanılarak tarafımızdan hazırlanmıştır.

Tablo 2 incelendiğinde 2012-2016 yılları arasında yapılan kamu alımlarının ortalaması alındığında \%85,52'sinin 4734 sayılı Kamu İhale Kanunu kapsamında yapılanlardan oluştuğu, geriye kalan \%14,48’lik kısmın ise diğer alım şekilleri çerçevesinde gerçekleştirildiği görülmektedir.

2012 yılından 2016'ya kadar geçen sürede doğrudan temin usulüyle yapılan alımlar ve istisna kapsamındaki alımlar tutar bazında incelendiğinde doğrudan temin alımlarında düşüş gözlenirken istisna kapsamındaki alımlarda yaklaşık aynı miktarlarda bir artış olduğu gibi bir görüntü ortaya çıkmaktadır. Bu alımların toplam kamu alımları içindeki yüzdesi ele alındığında ise istisna kapsamındaki alımların 2012'deki \%7,54 oranından büyük oranlı sapmalar olmadan 2016 yılında \%8,17 oranına geldiği görülmektedir. Ancak doğrudan temin alımlarının toplam kamu alımları içindeki 2012 yılında gerçekleşen \%11,18'lik payının 2013 yılında yarı yarıya bir düşüşle \%6,1 olarak gerçekleştiği, 2015 yılına kadar bu orana yakın bir seyir izlediği ve 2016 yılında \%60’lık bir düşüşle \%2,2 oranına kadar gerilediği görülmektedir.

\section{Kamu Alımlarının Ihale Usullerine ve Türlerine Göre Incelenmesi}

Tablo 3'de gösterildiği üzere 2012 - 2016 yılları arasında gerçekleşen kamu alımlarının 4734 sayılı Kanunda belirtilen açık ihale, belli istekliler arasında ihale ve pazarlık usulü kapsamında yapıldığı, alımların mal, yapım ve hizmet (danışmanlık hizmet alımı ayrı olmak üzere) alımı türlerine göre gerçekleştiği anlaşılmaktadır.

2012-2016 yılları arasındaki alımların ortalama \%82 gibi büyük bir oranla "açık ihale usulü" kullanılarak yapıldığı anlaşılmaktadır. Geriye kalan alımların \% 11’i pazarlık usulü, \%7’si ise belli istekliler arasında ihale usulü ile gerçekleştiği görülmektedir.

Kamu alımları içindeki en önemli alım kaleminin ise ortalamada \%50 ile "yapım işleri” olduğu görülmektedir. Bunu yine beş yıllık ortalamada \%31 ile hizmet alımları(danışmanlık hizmet alımları dahil) takip etmekte ve son sırada \%19'luk payı ile mal alımları yer almaktadır. 
Aşağıdaki Tablo 4'Te ise 2012-2016 yılları arasında 4734 sayılı Kamu İhale Kanununda belirtilen ihale usulleri kapsamında yapılan kamu alımlarının alım türlerine göre hesaplanan yaklaşık maliyetleri ile gerçekleşen sözleşme bedelleri toplu halde gösterilmiştir.

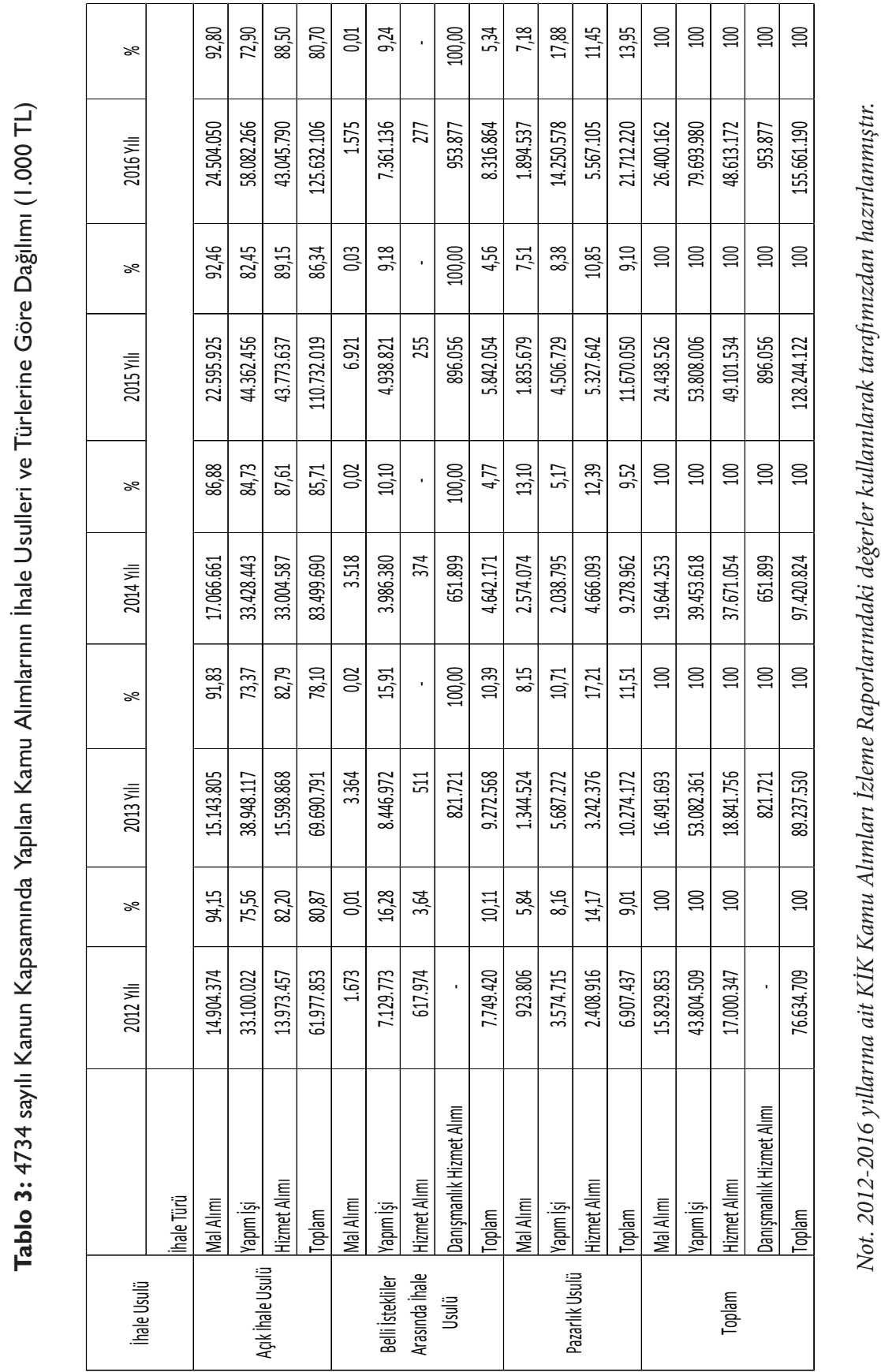




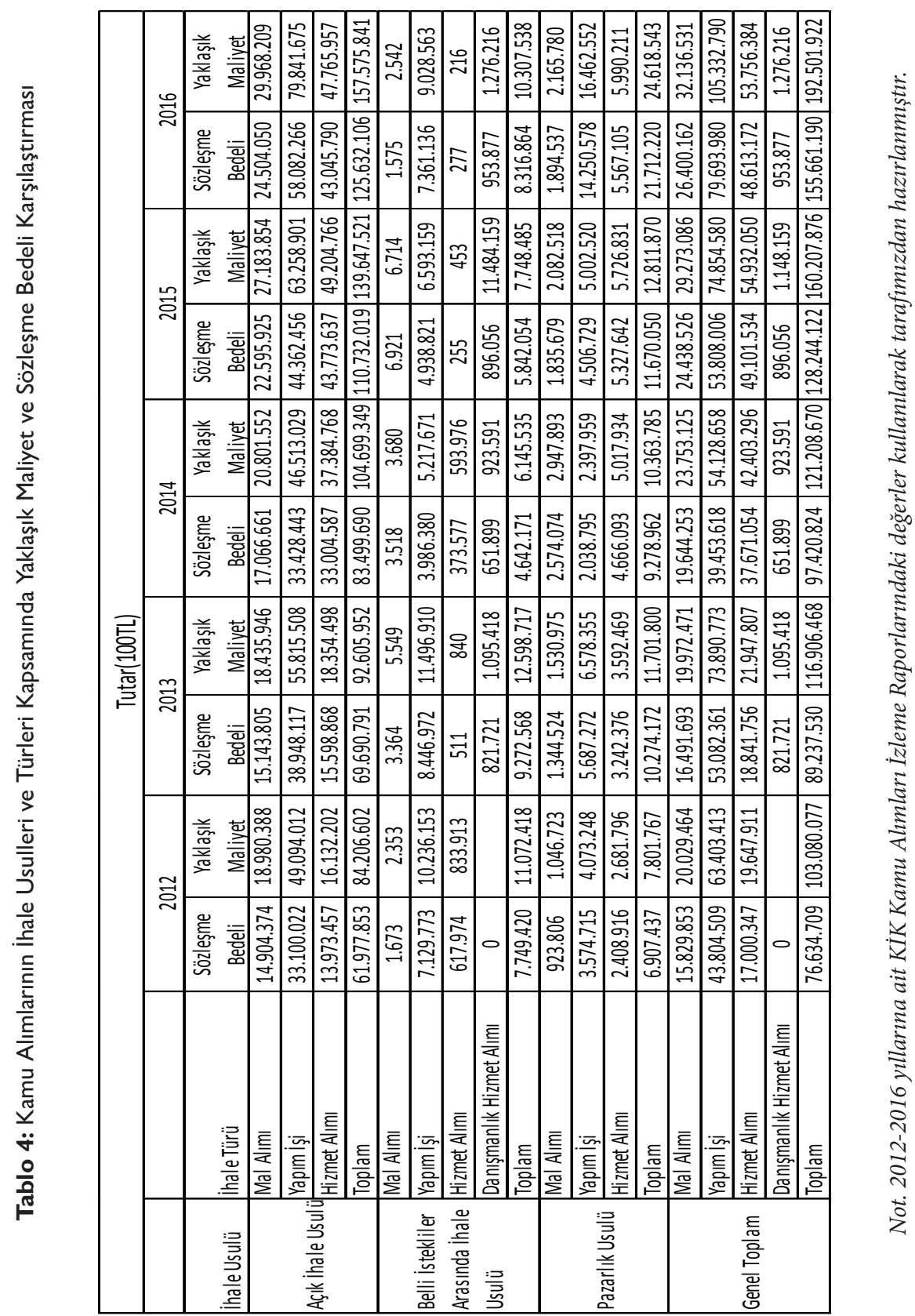


Alım türleri genel toplamı verilerine göre 2012-2016 yıllarına ait 5 yıllık ortalamada;

- Mal alımlarında, sözleşme bedelinin yaklaşık maliyetin \%18’i oranında altında,

- Yapım işlerinde, sözleşme bedelinin yaklaşık maliyetin \%28’i oranında altında,

- Hizmet alımlarında, sözleşme bedelinin yaklaşık maliyetin \%12'si oranında altında,

- Danışmanlık hizmet alımlarında ise sözleşme bedelinin yaklaşık maliyetin \%25’i oranında altında gerçekleştiği böylece yaklaşık maliyetle sözleşme bedeli arasındaki en büyük oran farkının \%28’le yapım işlerinde gerçekleştiği görülmektedir.

Yapım işlerinde yaklaşık maliyet ile sözleşme bedeli arasında gerçekleşen bu yüksek farkın nedeni olarak kamu yapım işlerinde resmi kurumlar tarafından hazırlanan birim fiyatların etkisi bulunmaktadır. Kamu tarafından yaptırılan yapım işlerine yönelik birim fiyat, tarif vb. hazırlama ile bunları yayımlama yetkisi başta Çevre ve Şehircilik Bakanlığı Yüksek Fen Kurulu Başkanlığı olmak üzere bu alandaki işlerin çeşitliliği, yapılan işe göre yapım kriterlerinin değişiklik göstermesi vb. sebeplerle farklı on bir kuruma verilmiştir. Bu çerçevede Bayındırlık Bakanlığı, Bayındırlık Kurulu, Bayındırlık Meclisi’nin 06.04.1955 yılında aldığı 60 sayılı karar ile inşaat işlerindeki kâr ve genel gider oranı \%25 olarak belirlenmiş olduğundan bu resmi kurumlar tarafından yayımlanan birim fiyatlar günümüzde \%25 oranında müteahhit kârı ve genel gider dahil olarak yayımlanmaktadır. Bu nedenle kamu idareleri tarafından ihtiyaç duyulan yapım işlerinin yaklaşık maliyetlerin hesaplanmasında öncelikle bu \%25 kârlı birim fiyatlar kullanılmaktadır. Bu resmi fiyatların yetersiz geldiği durumlarda ise piyasa fiyatlarına da başvurulmaktadır. Bu durumda Tablo 4'de de görüldüğü üzere yapım işlerinin yaklaşık maliyeti ile sözleşme bedeli arasındaki \%28’lik farkın yetkili resmi kurumlar tarafından hazırlanan \%25 kâr oranlı birim fiyat cetvelleriyle uyum gösterdiği değerlendirilmektedir Yapım işlerindeki bu fark ihale usulü bazında incelendiğinde ise açık ihale usulünde ortalama farkın \%30, belli istekliler arasında ihale usulünde ortalama farkın \%25, pazarlı usulünde ise ortalama farkın \%12 seviyesinde olduğu görülmektedir.

Yapım işlerinde sözleşme bedeli yaklaşık maliyet farkının yukarıda açıklanan nedenle yüksekliğine rağmen pazarlık usulü alımlarda bu oranının ortalamada \%12 olması dikkat çekicidir. Pazarlık usulünün yapım işlerindeki bu düşük oranı diğer alım türlerinde de pazarlık usulünün oranlarını incelemeye sevk etmektedir. Pazarlık usulünde sözleşme bedeli yaklaşı maliyet oranları arasındaki farkın mal alımlarında \%13 ve hizmet alımlarında ise \%9 oranında olması ise pazarlık usulünde gerçekleşen bu düşük oran farkının tüm alım türlerinde ortaya çıkan bir husus olarak karşımıza çıkmaktadır. Bunun nedeninin ise pazarlık usulünün uygulama gerekçelerinde ve uygulama usullerinde aranması gerekmektedir. Yaklaşık maliyetin yapım işlerinde en az \%25 kâr payıyla ve diğer alımlarda ise sağlıklı olarak hesaplanmadığından yüksek belirlemiş olması gerçeğiyle birlikte pazarlık usulü alımların neredeyse tamamına yakınının ilansız olarak gerçekleştirildiği göz önüne alındığında idarelerin alımlara davet ettikleri isteklilerin rekabetten uzak olarak gerçekleşen bu tür alımlarda fiyat tekliflerini yüksek tuttuğu ve böylelikle sözleşme bedellerinin yaklaşık maliyetlere daha yakın olarak gerçekleştiği değerlendirilmektedir. 
Yapım işlerindeki sözleşme bedeli ile yaklaşık maliyetin arasında oluşan \%28'lik farkın kabul edilebilir bir zemine oturtulabilmesine rağmen mal alımlarında gerçekleşen \%18’lik farkta bu hususu yine mevzuata bağlamak mümkün görünmemektedir. Mal alımların çok büyük çoğunluğunun istisnai haller hariç olmak üzere her yıl rutin olarak alınan mallara ait olduğu göz önüne alınırsa alım yapan idarelerin yaklaşı maliyeti tespit etmedeki bu isabetsizliğinin uzman personel tarafından gerçekleştirilmemesi, gerçeğe en yakın tutarları yansıtacak miktar ve çeşitlilikte satıcıdan fiyat teklifi alınmamasında ve idare tarafından aynı mala ait önceki yıllardaki alım fiyatları ile aynı malı tedarik eden diğer idarelerin alış fiyatlarına ulaşamamak gibi nedenlere dayandığı değerlendirilmektedir.

\section{Doğrudan Temin Usulü Ille Gerçekleştirilen Kamu Alımlarının Incelenmesi}

Tablo 5'de 2012-2016 yılları arasında doğrudan temin usulü ile gerçekleştirilen kamu alımları; mal, hizmet, yapım işi ve danışmanlık hizmet alımı olmak üzere türlerine göre gösterilmiştir.

Tablo 5: Doğrudan Temin Kapsamında Gerçekleştirilen Kamu Alımlarının Türlerine Göre Dağılımı (I.000 TL)

\begin{tabular}{|c|c|c|c|c|c|c|c|c|c|c|}
\hline \multirow[b]{2}{*}{ ALIM TÜRÜ } & \multicolumn{10}{|c|}{ Kamu Alımı Tutarı } \\
\hline & 2012 yılı & $\%$ & 2013 yılı & $\%$ & 2014 yılı & $\%$ & 2015 yılı & $\%$ & 2016 yılı & $\%$ \\
\hline Mal Alımı & 4.974 .930 & 47,14 & 3.804 .932 & 59,14 & 5.242 .381 & 70,65 & 5.580 .362 & 67,42 & 2.249 .199 & 58,91 \\
\hline Yapım İşi & 337.053 & 3,19 & 357.942 & 5,56 & 273.338 & 3,68 & 465.728 & 5,63 & 217.110 & 5,69 \\
\hline Hizmet Alımı & 5.242 .273 & 49,67 & 1.942 .363 & 30,19 & 1.671 .716 & 22,53 & 2.218 .620 & 26,81 & 1.341 .993 & 35,15 \\
\hline $\begin{array}{l}\text { Danışmanlık } \\
\text { Hizmet Alımı }\end{array}$ & - & - & 328.537 & 5,11 & 232.548 & 3,13 & 12.052 & 0,15 & 9.440 & 0,25 \\
\hline Toplam & 10.554 .256 & 100,00 & 6.433 .774 & 100,00 & 7.419 .983 & 100,00 & 8.276 .761 & 100,00 & 3.817 .742 & 100 \\
\hline
\end{tabular}

Not. 2012-2016 yıllarına ait KİK Kamu Alımları İzleme Raporlarındaki değerler kullanılarak tarafımızdan hazırlanmıştır.

Doğrudan temin usulü ileyapılan kamu alımlarıverileri incelendiğinde "mal ve hizmet alımlarının" bu alım usulünün yaklaşık olarak \%95’ini oluşturduğu görülmektedir. Mal alımlarının oran ve tutar bazında hizmet alımı ve yapım işlerinden belirgin olarak yüksek olmasının sebebi olarak ivedi ihtiyaçların piyasadan karşılanmasında mal alımları anında yerine getirilebilen türde olması yönüyle en uygun alım türü olarak gösterilebilir. Bu hususun tersi olarak ise yapım işlerinin genelinin yüksek bedelli olması ve gerçekleştirilmesinin uzun süreler alabilmesi doğrudan temin usulü ile gerçekleştirilen yapım işlerinin oran ve tutar bazında çok düşük seviyelerde kalmasının sebebi olarak değerlendirilebilir.

\section{İstisna Kapsamında Gerçekleştirilen Kamu Alımlarının Incelenmesi}

Tablo 6'da 2012-2016 yılları arasında 4734 sayılı Kamu İhale Kanunu’nun istisnalarının sıralandığı 3’üncü maddesi kapsamında yapılan kamu alımları alım türlerine göre gösterilmiştir. 
Tablo 6: İstisna Kapsamında Gerçekleştirilen Kamu Alımlarının İhale Türlerine Göre Dağıımı (I000 TL)

\begin{tabular}{|c|c|c|c|c|c|c|c|c|c|c|}
\hline \multicolumn{11}{|c|}{ KAMU ALIMLARI } \\
\hline İhale Türü & 2012 yılı & $\%$ & 2013 yılı & $\%$ & 2014 yılı & $\%$ & 2015 yılı & $\%$ & 2016 yılı & $\%$ \\
\hline Mal Alımı & 4.504 .077 & 63,24 & 6.259 .579 & 67,94 & 5.352 .893 & 63,78 & 7.350 .902 & 61,7 & 9.090 .762 & 64.09 \\
\hline Yapım İși & 691.481 & 27,05 & 833.647 & 9,05 & 561.560 & 6,69 & 442.885 & 3,72 & 854.649 & 6.3. \\
\hline Hizmet Alımı & 1.926 .166 & 9,71 & 2.113 .060 & 22,93 & 2.464 .972 & 29,37 & 4.110 .247 & 34,5 & 4.160 .061 & 29.33 \\
\hline $\begin{array}{l}\text { Danışmanlık } \\
\text { Hizmet Alımı }\end{array}$ & - & - & 7.184 & 0,08 & 13.976 & 0,17 & 9.870 & 0,13 & 79.431 & 0.56 \\
\hline Toplam & & 100 & 9.213 .471 & 100 & 8.393 .401 & 100 & 11.913 .904 & 100 & 14.184 .903 & 100 \\
\hline
\end{tabular}

Not. 2012-2016 yillarına ait KIK Kamu Alımları Izleme Raporlarındaki değerler kullanilarak tarafımızdan hazırlanmıştır.

İstisna kapsamında yapılan alımlar içinde "mal alımlarının” 2012-2016 yılları arasını kapsayan beş yıllık süreçte istikrarlı bir seyre sahip olduğu ve toplam istisna alımları içinde ortalama \%64'lük oranla en yüksek orana sahip alım türü olduğu görülmektedir. Mal alımlarını ortalamada \%25’lik oranla "hizmet alımlarının" takip ettiği görülmektedir. Ayrıca hizmet alımlarının 2013 yılından itibaren oran ve tutar bazında bir artış eğilimine girdiği de görülmektedir.

Tablo 7'de yer alan veriler beş yıllık ortalamaya göre incelendiğinde istisna alımları içinde en yüksek payın toplamda yaklaşık olarak $\% 78$ ile 3/g ve 3/b maddelerinden oluştuğu görülmektedir. Bu büyük payın ise \%50'si 3/g maddesi kapsamında yapılan alımlara aitken \%28'si 3/b maddesi kapsamındaki alımlara aittir.

4734 sayılı Kamu İhale Kanunu'nun 3/g maddesi “genel ve özel bütçeli idarelerin, il özel idareleri ve belediyeler ile bunlara bağl döner sermaye, birlik, tüzel kişilerin; kamu iktisadi teşebbüslerinin, sosyal güvenlik kuruluşlarının, fonların, özel kanunlarla kamu görevi verilmiş tüzel kişiliklerin, bağımsız bütçeli kuruluşların doğrudan veya dolaylı olarak birlikte ya da ayrı ayrı sermayesinin yarısından fazlasına sahip bulundukları her çeşit kuruluş, müessese, birlik, işletme ve şirketlere ticarî ve sinaî faaliyetleri çerçevesinde; doğrudan mal ve hizmet üretimine veya ana faaliyetlerine yönelik ihtiyaçlarının temini için yapacakları, Hazine garantisi veya doğrudan bütçenin transfer tertibinden aktarma yapmak suretiyle finanse edilenler dışındaki yaklaşık maliyeti ve sözleşme bedeli 2017 yılı için 8.980.120 (sekizmilyondokuzyüzseksenbinyüzyirmi) Türk Lirasını aşmayan mal veya hizmet alımlarını" kapsamaktadır. 
Tarihsel Boyutu ile Kamu Alım Usullerindeki Gelişmeler ve Günümüzdeki Yapının Değerlendirilmesi

Tablo 7: İstisna Kapsamında Gerçekleştirilen Kamu Alımlarının İstisna Maddelerine Göre Dağııım (I000 TL)

\begin{tabular}{|l|l|l|l|l|l|}
\hline Kamu Alım Tutar1 & \multicolumn{5}{l|}{} \\
\hline İstisna Kanun Maddesi & $\mathbf{2 0 1 2}$ & $\mathbf{2 0 1 3}$ & $\mathbf{2 0 1 4}$ & $\mathbf{2 0 1 5}$ & $\mathbf{2 0 1 6}$ \\
\hline 3a & 153.109 & 152.561 & 247.950 & 430.734 & 661.907 \\
\hline 3b & $\mathbf{1 . 3 4 1 . 4 2 9}$ & $\mathbf{3 . 3 7 1 . 9 5 6}$ & $\mathbf{1 . 9 8 0 . 7 0 5}$ & $\mathbf{4 . 1 2 3 . 4 3 0}$ & $\mathbf{4 . 3 3 7 . 4 7 2}$ \\
\hline 3c & 41.210 & 33.810 & 212.685 & 428.952 & 204.688 \\
\hline 3d & 65 & 0 & 2.893 & 1.827 & 2.824 \\
\hline $3 \mathrm{e}$ & 350.420 & 325.817 & 121.364 & 777.477 & 508.557 \\
\hline 3f & 238.257 & 169.047 & 280.247 & 216.655 & 289.633 \\
\hline 3g & $\mathbf{4 . 1 0 7 . 9 1 3}$ & $\mathbf{4 . 2 7 5 . 0 7 0}$ & $\mathbf{4 . 9 3 0 . 0 2 2}$ & $\mathbf{5 . 3 7 9 . 2 1 6}$ & $\mathbf{6 . 5 7 6 . 0 1 0}$ \\
\hline 3h & 424 & 368 & 818 & 1.833 & 295 \\
\hline $3 \mathrm{i}$ & 671.792 & 601.496 & 482.828 & 375.067 & 1.374 .072 \\
\hline 3k & 40.529 & 48.432 & 77.827 & 61.135 & 106.986 \\
\hline $3 \mathrm{l}$ & 0 & 0 & 220 & 0 & 0 \\
\hline 3n & 1.853 & 46.064 & 33.898 & 95.555 & 91.509 \\
\hline 4964 Geçici Md.1 & 149.864 & 165.460 & 3.428 & 1.487 & 1.375 \\
\hline 3p & 4.578 & 4.732 & 7.724 & 5.874 & 7.415 \\
\hline 3r & 19.723 & 12.688 & 10.791 & 14.663 & 22.160 \\
\hline 4734 KíK geçici md 1 & 558 & 5.969 & 0 & 0 & 0 \\
\hline Toplam & 7.121 .725 & $\mathbf{9 . 2 1 3 . 4 7 1}$ & $\mathbf{8 . 3 9 3 . 4 0 1}$ & $\mathbf{1 1 . 9 1 3 . 9 0 4}$ & $\mathbf{1 4 . 1 8 4 . 9 0 3}$ \\
\hline
\end{tabular}

Not. 2012-2016 yıllarına ait KİK Kamu Alımları İzleme Raporlarındaki değerler kullanılarak tarafımızdan hazırlanmıştır.

4734 sayılı Kamu İhale Kanunu'nun 3/b maddesi ise "savunma, güvenlik veya istihbarat alanları ile ilişkili olduğuna veya gizlilik içinde yürütülmesi gerektiğine ilgili bakanlık tarafindan karar verilen veya mevzuatı uyarınca sözleşmenin yürütülmesi sırasında özel güvenlik tedbirleri alınması gereken veya devlet güvenliğine ilişkin temel menfaatlerin korunmasını gerektiren hallerle ilgili olan mal ve hizmet alımları ile yapım işleri”ni kapsamaktadır.

$\mathrm{Bu}$ çerçevede 3/b istisna alımlarının ülke savunması, güvenliği ve istihbaratı açısından önem arz eden konularda yapıldığı göz önüne alındığında istisna alımları içindeki payının dışarıda tutulması halinde toplam istisna alımları içinde tek başına sahip olduğu ortalama \%50'lik pay ile 3/g maddesi önem arz etmektedir. 2016 yılında toplam tutarı 6,5 milyar lirayı bulan 3/g alımlarının istisna kapsamında yapıldığı ve ayrıca 2012-2016 yıllarına ait Kamu İhale Kurumu Kamu Alımları İzleme Raporlarındaki “istisna kapsamında yapılan alımların idarelerin harcama yaptığı finansman kaynağına göre dağılımı” tablolarındaki verilere göre bahse konu alımların \%50'nin altına düşmediği, görülen oranının KİT ve BİT’ler tarafından yapıldığı göz önüne alındığında 4734 sayılı Kanunun rekabet, şeffaflık, eşit muamele ilkelerinin zedelendiği değerlendirilmektedir.

\section{Sonuç}

Kamu alımlarının gerçekleştirilmesinde kullanılan kamu ihale mevzuatının geçmişten günümüze dört kanun ile düzenlendiği, bu kanunların hepsinde temel usul olarak herkesin teklif verebildiği kapalı zarf usulüyle artırma veya eksiltme, kapalı zarf, açık ihale adlarındaki ihale usulünün ilk sırada yer aldığı 
anlaşılmıştır. Kamu ihalekanunundayeni düzenlemelerin yapılmasının tartışıldığı günümüzde(“Kamu ihale kanunu yine değişiyor", 2017), kanunda yapılacak değişiklik içinde adı açık ihale ya da kapalı zarf olsun bu usulünün temel usul olarak varlığının devam edeceğini söylemek yanlış olmayacaktır. 2012-2016 yıllarına ait veriler üzerinden yapılan incelemelerde günümüzdeki ihale kanununda temel usul olarak belirlenen açık ihale usulü ile yapılan kamu alımlarının ortalama \%82 oranında olması bu usulün önemini ortaya koymaktadır. Bu oran üzerinden konuyu detaylandırdığımızda geri kalan \%18’lik oranın da önemsenmesi gerektiği düşüncesi ağır basmaktadır. Bunun önemsenmesinin gerekliliğini parasal boyutu ile ifade etmek gerekir. İncelenen 2012-2016 ylları itibariyle toplam olarak yaklaşık altı yüz otuz beş milyar TL'lik (Tablo 1 ve 2) kamu alımları olduğu hesaba katıldığında bunun \%18’inin yüz on dört milyar TL olduğu dolayısıyla önemli bir meblağın açık ihale usulünün dışına kaydığını görebilmekteyiz. Açık ihale usulü dışındaki pazarlık ve belli istekliler arasında ihale usulü ile gerçekleştirilen bu büyüklükteki alımların belli bir düzen içinde yapıldığını söylemek mümkün olsa da yine de açı ihale kadar rekabetçi olmadıklarını söylemek gerekir. Örneğin; pazarlık usulünde -ki yüzde onsekizin yüzde on birini (Tablo 3) oluşturmaktadır - idare ile istekliler yakın iş birliği içinde olabilmektedirler. Bu usulün işleyişinde özellikle ilana tabi olmayan alımlarda idare, pazarlık için birkaç firma çağırarak alımı gerçekleştirebilmektedir. Bu ise piyasa oyuncuları arasındaki haksız rekabetin ortaya çıkmasına neden olabilen bir uygulama olmaktadır.

Kamu İhale Kanununun kapsamındaki ihale usullerinin dışında gerçekleșen diğer uygulamalarda dikkat çekici boyuta ulaşmışlardır. Kamu alımlarının 2012-2016 yılları arasında \%85,52'si ihale usulleri kapsamında yapılırken geri kalan \%14,48’i istisna, doğrudan temin ve kapsam dışı yollarla yapılmıştır. Bu görüntü açık ihale usulünün kuvvetlenmesini etkileyen daha vahim bir sonuç doğurmaktadır. İlgili yılların verileri (Tablo 2) ele alındığında ve hesaplama yapıldığında yaklaşık doksan iki milyar TL’lik meblağın ihale usullerinin dışında kaldığı anlaşılmaktadır. Bu alımlarla gerçekleşen işlemlerin bir usulü olmuş olsa da önemli olan husus, bu kadarlık bir büyüklügün rekabet ve şeffaflı̆̆ın göstergesi olan açık ihale usulünün dışında gerçekleşmiş olmasıdır.

Kamu alım usullerinde dikkat çeken bir husus ise yaklaşık maliyet ile sözleşme bedelleri arasındaki farklardır. Özellikle açık ihalelerde rekabetçi anlayış kuvvetli olduğundan sözleşmeler yaklaşık maliyetin çok altında kalarak (Tablo 4) idarelerin lehine bir durum oluşmaktadır. Ancak pazarlık usulüne bakıldığında yaklaşık maliyetler ile sözleşme bedelleri arasındaki farkın azaldığ 1 görülmektedir. Bu ise rekabetçi fiyat teklifini arka planda birakmakta, idare aleyhine bir durum oluşturmaktadır. Dolayısıyla pazarlık usulünün yanında kapsam dışı alım şekilleri ve doğrudan temin de dikkate alındığında kamu alımlarında önemli düzeyde yüksek maliyetlerde alımların gerçekleştiğini söylemek yanlış olmayacaktır.

Kamu alımlarında alım usullerinin tarihsel boyutta değişmediği, günün şartlarına göre rötuşlandığını söylemek gerekir. Bu hususta esas usulün her zaman günümüzdeki adıyla "açık ihale” usulü olduğu, büyük meblağların konu olduğu ihale çalışmalarının mümkün olduğunca açık ihale usulünün içine alınmasına çalışılması gerektiği, bu konuda idarelerin hızlı ve kolay alım yapmasını sağlayacak şekilde açık ihale usulünün uygulamasını kolaylaştıracak düzenlemelerin hayata geçirilmesi gerektiği söylenebilir. 


\section{Kaynakça}

Akdoğan, M. (2014). Avrupa Birliği Kamu Alımları Direktifleri Ve Türkiye Uygulamasına Yansımasının İlerleme Raporları Işs̆ğında Değerlendirilmesi. İstanbul Üniversitesi Hukuk Fakültesi Mecmuası, 72(2), 683-692.

Arrowsmith, S., \& Kunzlik, P. (2009) .Social And Environmental Policies In EC Procurement Law : New Directives And New Directions. Cambridge University Press,. ProQuest Ebook Central, http:// ebookcentral.proquest.com/lib/uludag-ebooks/detail.action?docID=424537. Created from uludagebooks on 2017-12-02 05:39:36.

Arslan, A. (2002). Kamu Harcamalarında Verimlilik, Etkinlik Ve Denetim. Maliye Dergisi, 140 ,6.

Artırma, Eksiltme ve İhale Kanunu.(1934,10 Haziran). Resmi Gazete (Sayı:2723)Erişim adresi: http://www. resmigazete.gov.tr/arsiv/2723.pdf

Büber, B. (2008). Yeni bir çatışma alanı: Kamu alımları. Yayımlanmamış Doktora Tezi. Ankara Üniversitesi Sosyal Bilimler Enstitüsü.

Büber, B. (2014). Kamu ihale mevzuatının genel çerçevesi. M.Çolak, D.A. Demirboğa, (Ed.), Kamu İhale Hukukunda Temel Konular içinde(90-101), Ankara: Kamu İhale Kurumu Yayınları.

Cumhuriyet döneminde ihale kanunları tarihi. (2017, 16 Aralık) Erişim adresi:

https://ihalemektebi.wordpress.com/mevzuat/cumhuriyet-donemi-ihale-kanunlari-tarihi/661-sayilimuzayede-munakasa-ve-ihalat-kanunu/

Çolak ,M. (2014). Kamu Alımlarında Doğrudan Temin Ve Eşik Değer Uygulaması, Avrupa Birliği Mukayesesi Ve Sonuçları. Vergi Sorunları Dergisi, (307), 114.

Devlet İhale Kanunu.(1983,10 Eylül). Resmi Gazete (Sayı:18161)Erişim Adresi: http://www.mevzuat.gov.tr/ MevzuatMetin/1.5.2886.pdf

Edizdoğan, N., Çetinkaya Ö. ve Gümüş, E. (2015) .Kamu maliyesi(6.Baskı). Bursa:Ekin Yayınevi.

İlkorkor, Z. Ş.,(2010) .Kamu Yönetiminde Etkinliğin Sağlanmasında Alternatif Bir Model: İhale Yöntemi. Türk İdare Dergisi, (468), 65.

Kamu İhale Kanunu.(2002,22 Şubat). Resmi Gazete (Sayı:24648)Erişim adresi: http://www.mevzuat.gov.tr/ MevzuatMetin/1.5.4734.pdf

Kamu ihale kanunu yine değişiyor. (2017, 28 Aralık). Erişim adresi: http://www.aljazeera.com.tr/haber/ kamu-ihale-kanunu-yine-degisiyor

Kamu İhale Kurumu, Kurumsal Gelişim Ve Araştırma Dairesi Başkanlığı.(2013). 2012 Yllı Ait Kamu İhale Kurumu Kamu Alımları İzleme Raporu. Erişim adresi: http://www2.ihale.gov.tr/ duyurular2012/2012_kamu_al\%C4\%B1m\%C4\%B1_istatistkleri_rev.pdf

KİK,KurumsalGelişim VeAraştırmaDairesiBaşkanlığı.(2014).2013YılıAitKamuİhaleKurumuKamuAlımları İzleme Raporu. Erişim adresi: http://www2.ihale.gov.tr/Duyurular2012/2013_y\%C4\%B1lsonu_ kamu_alimlari_istatistik_raporu.pdf

KİK, Kurumsal Gelişim Ve Araştırma Dairesi Başkanlığı.(2015). 2014 Yılı Ait Kamu İhale Kurumu Kamu Alımları İzleme Raporu. Erişim adresi: http://www2.ihale.gov.tr/Duyurular2012/2014_kamu_ alimlari_raporu.pdf

KİK, Kurumsal Gelişim Ve Araştırma Dairesi Başkanlığı.(2016). 2015 Yllı Ait Kamu İhale Kurumu Kamu Alımları İzleme Raporu. Erişim adresi: http://dosyalar.kik.gov.tr/genel/Raporlar/2015_yil_sonu_ kamu_alimlari_raporu_v2.pdf

KİK, Kurumsal Gelişim Ve Araştırma Dairesi Başkanlığı.(2017). 2016 Yılı Ait Kamu İhale Kurumu Kamu Alımları İzleme Raporu. Erişim adresi: http://dosyalar.kik.gov.tr/genel/Raporlar/kamu_alimlari_ izleme_rapor_2016_y\%C4\%B1lsonu.pdf 
Kanca, O. C:, Bayrak, M.(2015). Ekonomik tasnif esasında Türkiye’de kamu harcamaları. Muş Alparslan Üniversitesi Sosyal Bilimler Dergisi,3(1),s.107-139.

Kaplan, S. (2012). İdeal Bir Kamu İhale Kanunu Ve İdeal Bir Kamu İhale Kurumu Ve Kurulu Nasıl Olmalıdır? Fonksiyonel Bir Model Çalışması. Maliye Dergisi,(162),s 21.

Köktaş, A. (2005). Avrupa Birliğinde Kamu İhale Hukuku Ve AB Politikaları Arasındaki İlişki. Ankara:Asil Yayın Dağıtım.

Organization of Economic Cooperation and Development.(2017). Government At A Glance 2017 Edition. Erişim adresi:stats.oecd.org/\# 01.12.2017

Schapper, P.R., Malta, J. N. V. \& Gilbert, D. L. (2009). Analytical Framework For The Management And Reform Of Public Procurement. K. V. Thai (Ed.). International handbook of public procurement (87104), New York:CRC Press.

Thai, K.V. (2009). International Public Procurement: Concepts And Practices. K. V. Thai (Ed.). International handbook of public procurement(1-26), New York:CRC Press.

Türkiye Büyük Millet Meclisi, Danışma Meclisi. (1981). Devlet İhale Kanunu Tasarısı ve Bayındırlık, Ulaştırma, İmar ve İskân, Turizm ve Tanıtma ve İktisadî İşler Komisyonu Raporu.Erişim adresi: https://www.tbmm.gov.tr/tutanaklar/TUTANAK/DM_/d02/c020/dm_02020135ss0483.pdf

TBMM, (2001). Kamu İhale Kanunu Tasarısı ve Plan ve Bütçe ve Bayındırlık, İmar, Ulaştırma ve Turizm Komisyonu Raporu.Erişim adresi: https://www.tbmm.gov.tr/tutanaklar/TUTANAK/TBMM/d21/ c082/tbmm21082047ss0794.pdf

TBMM,(2003). Bazı Kanunlarda Değişiklik Yapılması Hakkında Kanun Tasarısı İle Kamu İhale Kanunu Ve Kamu İhale SözleşmeleriKanununda Değişiklik Yapılması Hakkında Kanun Tasarısı; Benzer Mahiyetteki Kanun Teklifleri Ve Bayındırlık, İmar, Ulaştırma Ve Turizm Komisyonu Raporu. Erişim adresi:

https://www.tbmm.gov.tr/tutanaklar/TUTANAK/TBMM/d22/c025/tbmm22025113ss0257.pdf

Wiehen, M., Olaya, J.(2006) How To Reduce Corruption İn Public Procurement. K. Kostyo(Ed.).Handbook for curbing corruption in public procurement (13-108). Retrieved December 02, 2017, from

http://issuu.com/transparencyinternational/docs/2006_curbingcorruptionpublicprocurement

Yılmaz, B. M. (2007). Kamu Alımlarında İdari Denetim. Ankara: Yetkin Yayınevi. 